\title{
Variations of Absorbed Photosynthetically Active Radiation over the Canadian Prairie in 2000-2008
}

\author{
Yan Yang, Shusen Wang(Corresponding Author) \& Alexander P. Trishchenko \\ Canada Centre for Remote Sensing, Natural Resources Canada \\ 588 Booth Street, Ottawa, Ontario, K1A 0Y7, Canada \\ Tel: 1-613-947-3592Ｅ-mail: Shusen.Wang@NRCan.gc.ca
}

Yi Luo

Canadian Ice Service, Environment Canada

373 Sussex Drive, Ottawa, Ontario, K1A 0H3, Canada

Xiaoyuan Geng

Canadian Soil Information Service, Agriculture and Agri-Food Canada

960 Carling Avenue, Ottawa, Ontario, K1A 0C6, Canada

Received: May 16, 2011

Accepted: June 13, $2011 \quad$ Online Published: December 21, 2011

doi:10.5539/jas.v4n2p57

URL: http://dx.doi.org/10.5539/jas.v4n2p57

The research is supported by the "Groundwater Geoscience Program" and the "Enhancing Resilience in a Changing Climate Program” of the Earth Sciences Sector, Natural Resources Canada.

\begin{abstract}
The fraction of absorbed photosynthetically active radiation (fAPAR) determines the absorption of solar radiation by vegetation and controls the ecosystem productivity. In this paper, the fAPAR over the Canadian Prairie eco-zone (hereafter the Prairie) was estimated for 2000-2008 using the 3-D canopy radiation transfer model implemented as part of the Ecological Assimilation of Land and Climate Observations (EALCO) model and the Moderate Resolution Imaging Spectroradiometer (MODIS) remote sensing data. With these estimates, the fAPAR magnitude, spatial distribution, and inter-annual variations due to the impact of climate variations were investigated. It was found that the Prairie-scale average fAPAR during the peak growing season was around 0.56 during the nine study years. The inter-annual variation of fAPAR was significantly related to the climate variations over the region, with precipitation being the most important factor. The severe droughts in 2001 and 2002 over the Prairie resulted in $11.5 \%$ and $15.2 \%$ reduction respectively compared to the 9 -year average fAPAR. The spatial variation of fAPAR over the Prairie was largely determined by vegetation types, growing conditions, soil types, and climate factors such as precipitation and temperature. Among the seven eco-regions in the Prairie, the fAPAR was found to be the highest in Aspen Parkland eco-region, owing to the well-growing trembling aspen, mixed tall shrubs and intermittent fescue grasslands under the conditions of favorable precipitation and fertile black soils. The fAPAR was the lowest in Mixed Grassland eco-region where about half the region was cultivated and the remainder was used for pasture or rangeland. This region had the lowest precipitation (250-350 mm per year) in the Prairie.
\end{abstract}

Keywords: fAPAR, Canadian Prairie, Drought, MODIS, EALCO model, Climate impact

\section{Introduction}

The fraction of photosynthetically active radiation $(0.4-0.7 \mu \mathrm{m})$ absorbed by a vegetation canopy (fAPAR) acts as an integrated indicator of the status and health of vegetation. It plays an important role in the determination of the productivity of the land biosphere (e.g. Prince, 1991; Running et al., 1999; Plummer et al., 2006). The fAPAR has been recognized as one of fundamental surface geophysical quantities for the Earth climate studies (e.g. by Global Climate Observing System (GCOS) and United Nations Framework Convention on Climate Change (UNFCCC) (GCOS, 2006). It is also one of the ctritical variables in many models of climate, ecology, and hydrology (e.g. Sellers et al., 1996; Knorr and Kattge, 2005). 
Known as the 'Breadbasket of Canada', the Canadian Prairie (including the southern parts of Alberta, Saskatchewan, and Manitoba provinces, see Figure 1) contains the majority of the Canada's productive agricultural cropland, pasture, and rangeland. The Canadian Prairie is very susceptible to drought because it experiences high precipitation variability both spatially and temporally (Bonsal and Wheaton, 2005). Economy of the region is more vulnerable due to its dependence on agriculture. In the most recent prairie drought in 2001 and 2002 when the precipitation was $10 \%$ to $50 \%$ below normal (Bonsal and Wheaton, 2005, Hanesiak et al., 2011), the Canadian prairies suffered a loss of $\$ 4.5$ billion Canadian dollars and this is considered one of Canada's worst natural disasters (Wheaton et al. 2008). Therefore monitoring the status and health of vegetation and understanding the climate effects are especially important in this region.

Satellites with optical remote sensing sensors, e.g. Moderate Resolution Imaging Spectroradiometer (MODIS), Multiangle Imaging Spectroradiometer (MISR), Medium Resolution Imaging Spectrometer (MERIS), and Advanced Very High Resolution radiometer (AVHRR), are most appropriate for monitoring large scale temporal and spatial distributions of fAPAR and hence the strength and location of productivity over vegetated land surfaces. One widely used approach is to correlate the normalized differential vegetation index (NDVI) with fAPAR. The relationship between NDVI and fAPAR has been found to be linear or approximately linear for green vegetation (Prince and Goward, 1995). The in situ measurements also suggested a linear relationship for wheat (Hatfield et al., 1984), millet (Begué, 1993), and semi-arid grass savannah (Fensholt et al., 2004). However Le Roux et al. (1997) found the relation to be nonlinear for humid savannah grassland. Though many of these studies provided a simple relationship between NDVI and fAPAR estimates, they were based on statistical regression method. Thus, it may bring large uncertainties and biases while applies these statistical relationships under different environments.

Physically-based canopy radiation transfer models have also been used to retrieve fAPAR (e.g. Knyazikhin et al. 1998; Pinty et al. 2007). The MODIS global fAPAR product is derived from a global-scale process model on the basis of biome-specific algorithms (Knyazikhin et al., 1998). As noticed by Fensholt et al. (2004), this method underestimated the multiscattering between crowns and had tendency to overestimate fAPAR by $8-20 \%$ in semi-arid West Africa and Senegal. The Joint Research Centre (European Commission) MODIS fAPAR product is estimated based on the rectified red and near-infrared channel reflectance, and coefficients in the algorithms are determined by forcing fAPAR value to be as close as possible to fAPAR associated with the plant canopy scenarios used in the training data set (Gobron et al., 2006). A look up table of bidirectional reflectance factors is created using the semi-discrete model of Gobron et al. (1997) to represent the spectral and directional reflectance of plant canopies, as well as to calculate the values of fAPAR. This model involves a number of simplifications such as horizontally uniform canopy. Pinty et al. (2007) retrieved fAPAR using the inversion of two-stream radiation transfer scheme. The effective variables are used in this scheme to account for the effects induced by canopy structure and heterogeneity at grid cell level. However, robust estimation of grid cell effective parameters, depending on the land cover types and environmental factors such as Solar Zenith Angle (SZA), still requires further studies.

In a recent study, Wang (2005) developed the canopy radiation transfer model using the gap probability approach of Nilson (1999) and successive orders of scattering approximation. The model treats canopies as being composed of 3-D stands and explicitly accounts for the spatial heterogeneity of stands as well as clustering of plant tissues. It includes multiple layers of canopy and multi-scattering between and within crowns. This approach represents an intermediate solution between numerical scheme like 3-D methods and analytical scheme like two-stream solution. The improvement of this approach in simulating the canopy radiation absorption and land surface albedo has been demonstrated in the study of Widlowski et al. (2011). This canopy radiation transfer model is now utilised as the radiation model in the land surface model of EALCO (Wang et al., 2007; Wang, 2008).

In this study, the EALCO model is calibrated using the same spectral bands as MODIS to simulate NDVI and fAPAR simultaneously. The model results provide the relationships for mapping the Prairie fAPAR using the MODIS NDVI. The main objectives of this study was to derive fAPAR in the Canadian Prairie during peak growing season $(2000-2008)$ and to investigate the spatial patterns and inter-annual variations of fAPAR and their causality with ecosystem characteristics and climate variations.

\section{Study area}

The Prairie is part of the Interior Plains of Canada (Figure 1). It covers the southern part of Alberta, Saskatchewan, and Manitoba, stretching from the Rocky Mountains in Alberta to the Red River valley in Manitoba. The Prairie is further divided into seven Prairie eco-regions: Aspen Parkland, Moist Mixed Grassland, Fescue Grassland, Mixed Grassland, Cypress Upland, Lake Manitoba Plain and Boreal Transition. Their characterizations, including vegetation types, dominant soil types, mean annual/summer temperature, mean annual precipitation and area coverage are summarized in Table 1. It shows that the Prairie is dominated by three eco-regions, namely Aspen 
Parkland (37.6\%), Mixed Grassland (28.9\%) and Moist Mixed Grassland (21.5\%), which account for 88\% of the total area.

The Prairie's climate is pronounced sub-humid to semi-humid which is determined by its location in the heart of North America and by the neighboring Rocky Mountains, which block the moisture-bearing winds from the Pacific. Mean annual temperatures over the region range from $1.5^{\circ} \mathrm{C}$ to $3.5^{\circ} \mathrm{C}$. Winters are long and cold with the lowest mean monthly temperature of $-18.3^{\circ} \mathrm{C}$ at Winnipeg. Summers are short and warm with the highest mean monthly temperature of $19.7^{\circ} \mathrm{C}$ at Winnipeg. Annual precipitation is extremely variable, ranging from $250 \mathrm{~mm}$ in the arid grassland regions of southwest Saskatchewan and southeast Alberta (Mixed Grassland eco-region) to almost $700 \mathrm{~mm}$ in the Lake Manitoba plains and Boreal Transition eco-regions. About $70 \%$ of the annual precipitation falls as rain; and $75 \%$ of the rain falls during the growing season (May-August) (Akinremi and McGinn, 2001). Thunderstorms in summer are a common occurrence over the Prairie. In some places mean annual wind speed could reach 18 to $21 \mathrm{~km} / \mathrm{h}$, resulting in the high atmospheric evaporation demand and much of the dryness.

The Prairie is dominated by four chernozemic soil types: brown, dark brown, black, and dark grey soils. Brown Chernozemic soils, which have a moderate amount of organic material, dominant in Mixed Grassland. Dark brown Chernozemic soils, which are well drained and have greater accumulation of organic matter than brown soils, are found in Moist Mixed Grassland and Cypress Upland. Black Chernozemic soils, which are well-drained and have a high organic material content, are found in Aspen Parkland, Fescue Grassland, Cypress Upland and Lake Manitoba Plain. Dark Gray Chernozemic soils, which have relatively little organic material, are mainly found in Boreal Transition.

The Prairie has been radically transformed to farmland (nearly $94 \%$ of the land use). It contains the majority of Canada's productive agricultural cropland, rangeland, and pasture. Agricultural crops include spring wheat (Triticum spp.), other cereal grains, oilseeds, forages, etc. Only a small fraction remains in its native state. Natural vegetation is generally dominated by Spear Grass (Imperata cylindrica), Wheat Grass (Triticum aestivum), and Blue Grama Grass (Bouteloua gracilis ). Sagebrush (Artemisia tridentata) is also abundant.

\section{Data and Methodology}

In this study, the regional fAPAR was estimated using MODIS data and the canopy radiation transfer module of the EALCO model. Field measurements of downward and upward PAR were made at two levels of above and below the canopy to obtain in situ fAPAR for validation purpose. Detailed descriptions are given as follows.

\subsection{MODIS Data}

MODIS/Terra clear-sky 10-day composites generated at the Canada Centre for Remote Sensing (CCRS) (Luo et al., 2008) were used. The data included seven land spectral bands (B1 to B7) at $250 \mathrm{~m}$ spatial resolution. One of the major advantages of these MODIS data was the spatial quality improvement in the mid to high latitude region compared to the standard MODIS data products that use global sinusoidal (SIN) projection. The new cloud shadow detection technique combined geometrical and spectral approaches and used the spectral features of four MODIS land bands (B1, B2, B3 and B6). The new clear-sky compositing scheme, which employed scene identification and a scene-dependent decision matrix, provided better results than others based on single compositing criterion, such as maximum NDVI or minimum visible reflectance. The data products were mapped in the Lambert Conformal Conic (LCC) projection which was a standard map projection used at CCRS for satellite data over Canada. A detailed description of the MODIS products, their creation, and validation was provided by Luo et al. (2008). Our study focused on 10-day composites of July $11^{\text {th }}$ to $20^{\text {th }}$ for $2000-2008$. Mid-July is the time period when most crops and grasses in the Prairie are at the peak growing stage.

The MODIS red channel (B1, with bandwidth of 620-670 nm) reflectance $\left(\alpha_{R E D, M O D I S}\right)$ and near-infrared channel (B2, with bandwidth of $841-876 \mathrm{~nm})$ reflectance $\left(\alpha_{N I R, M O D I S}\right)$ were used to calculate MODIS NDVI:

$$
N D V I_{M O D I S}=\frac{\alpha_{N I R, M O D I S}-\alpha_{R E D, M O D I S}}{\alpha_{N I R, M O D I S}+\alpha_{R E D, M O D I S}}
$$

\subsection{EALCO model}

The canopy radiation transfer model in the land surface model EALCO (Wang, 2005; Wang, et al., 2007) was used to simulate fAPAR and NDVI. The EALCO model simulates land surface radiation reflectance and absorption by different ecosystem elements (e.g., plant leaves, stems, soil, and snow) at user-defined number of wavebands at different wavelength. Previous model tests using measurements from various ecosystems showed that the model well reproduced the observed diurnal and seasonal dynamics of canopy radiation absorption and reflection under different weather and ecosystem conditions (Wang, 2005, Wang, et al., 2007, Widlowski, et al., 
2011). In this study, EALCO was configured to run at three wavebands: visible broadband (400-700 nm), red $(620-670 \mathrm{~nm})$ and near infrared $(841-876 \mathrm{~nm})$. The red and near infrared bands were the same as the MODIS B1 and B2, respectively. The canopy absorption simulated by the EALCO model at the visible broadband is fAPAR. The EALCO simulated NDVI is calculated as:

$$
N D V I_{\text {Model }}=\frac{\alpha_{N I R, \text { Model }}-\alpha_{R E D, \text { Model }}}{\alpha_{N I R, \text { Model }}+\alpha_{R E D, \text { Model }}}
$$

where $\alpha_{R E D, M o d e l}$ and $\alpha_{N I R, \text { Model }}$ are the land surface red and near infrared narrowband reflectances simulated by the EALCO model.

The regional fAPAR was obtained by running EALCO at each pixel using the criterion of $/ N D V I_{M O D I S}-N D V I_{\text {Model }} /<0.01$. In this study, the spatial resolution is taken the same as MODIS data (250m). The digital land cover map of North America 2000 (Latifovic and Pouliot, 2005) was used to map the spatial distribution of land cover types across the Prairie. Two land cover types, cropland and grassland, were recognized in the model parameterization. The canopy-related input parameters for these two land covers are given in Table 2.

\subsection{In situ measurements}

Field measurements were conducted to obtain in situ fAPAR for model validation. The field campaign was made across the Prairie from July 8 to July 15, 2008. It encompassed different biome types and plant growing conditions. The observed vegetation types included canola and wheat, the most popular crops in the Prairie, as well as grass and corn. The detailed descriptions of measurement latitude, longitude, vegetation types and growing stages are shown in Table 3. The instrument TRAC (Leblanc, 2002) was used for the measurements. TRAC had three sensors: two of them recorded the downward flux and one recorded the upward flux of PAR. The measurements were made at a frequency of $32 \mathrm{~Hz}$. Downward and upward PAR was measured at two levels: above and below the canopy. Observed fAPAR was then calculated as the ratio of net PAR absorbed by the canopy to the downwelling PAR above the canopy as defined below:

$$
f A P A R_{o b s}=\frac{\left(F_{d 1}-F_{u 1}\right)-\left(F_{d 2}-F_{u 2}\right)}{F_{d 1}}
$$

where $F_{d l}$ and $F_{u l}$ were the downwelling (incident) and upwelling (reflected) PAR above the canopy, respectively, and $F_{d 2}$ and $F_{u 2}$ were the corresponding terms below the canopy.

\section{Results and discussion}

\section{1 fAPAR Validation}

The comparison of modeled versus observed fAPAR is shown in Figure 2. The descriptions of observation sites are shown in Table 3. For the entire data, the correlation coefficient $(R)$ between modeled and observed fAPAR was 0.81 and the average absolute error was 0.035 , indicating a general agreement. Figure 2 showed fAPAR was lowest for grassland and highest for canola at its full growing stage. With respect to the different growing seasons of canola, fAPAR increased from 0.62 at early growing stage to around 0.81 at flowering stage. As for wheat, the highest fAPAR was also observed at the flowering stage. In the later grain filling stage, fAPAR started to decrease as the lower leaves started senescing. Compared with canola, the variation of fAPAR for wheat at different growth stages was relatively small because measurements spanned over a relatively short period from heading emergence to grain filling stage. The area for corn plant in the Prairie was much smaller than that for wheat and canola and only one corn site was observed. The observed corn fAPAR at V6 stage (a plant with 6 leaf collars) was 0.66, its modeled fAPAR was a little lower than in the observed fAPAR as 0.63 . The comparison between observed and modeled fAPAR suggested the model simulated fAPAR fairly well at different phonological stages.

\section{2 fAPAR Spatial and Temporal Distributions}

The 9-year average fAPAR for 2000-2008 during July $11^{\text {th }}$ to $20^{\text {th }}$ is shown in Figure 3 . The average fAPAR appeared to be lowest in the middle of the Prairie and gradually increased towards northern and eastern parts. The spatial pattern of fAPAR showed that Boreal Transition, Lake Manitoba Plain, Aspen Parkland and Fescue Grassland had high fAPAR (0.6 - 0.8); Moist Mixed Grassland and Cypress Upland had intermediate values (0.4 0.6 ), and Mixed Grassland had fAPAR values generally lower than 0.4. fAPAR varies in space and time depending on vegetation type and abundance, its growing state, and environmental factors affecting vegetation vigor such as water availability, temperature extremes, wind, disease, fire and anthropogenic interventions such as fertilization and irrigation (GCOS, 2003; Global Terrestrial Observing System, 2008). Favorable conditions are associated with high fAPAR values whilst stress cause fAPAR values to fall (Gobron et al., 2010). In the Mixed Grassland eco-region, about half of the area was used for pasture or rangeland where vegetation density was very low even in the peak growing season, which resulted in the less radiation absorption by canopy thus low 
fAPAR. In Boreal Transition eco-region, the upper elevations had a closed cover of tall trembling aspen where the canopy intercepted more radiation and the corresponding fAPAR was high. The fAPAR could reach over 0.8 in the regions of trembling aspen in Aspen Parkland, Lake Manitoba Plain and mountain-type open forest in Cypress Upland. Over the Canadian Prairie, vegetation species are associated with precipitation and soil types, which determine the maximum fAPAR they can reach. Table 1 shows that high precipitation and black soils in Boreal Transition, Lake Manitoba Plain, Aspen Parkland and Fescue Grassland correspond to high fAPAR, and low precipitation and brown soils in Mixed Grassland eco-region correspond to low fAPAR.

The regional fAPAR for each individual year of 2000-2008 is presented in Figure 4. Substantial inter-annual variations can be seen over the 9 study period. Overall, fAPAR in 2001 decreased dramatically in Mixed Grassland (below 0.2), Cypress Upland, parts of Aspen Parkland and Fescue Grassland. While in 2002, fAPAR decreased in the northwest regions of the Prairie, including parts of Aspen Parkland and Moist Mixed Grassland. In 2003 fAPAR is lower than normal in Aspen Parkland and Moist Mixed Grassland over the Saskatchewan region. The fAPAR around Winnipeg showed extraordinary low in 2005. The fAPAR in other years and regions had relatively small variations. The fAPAR anomalies over the entire Prairie are shown in Figure 5. Among the nine years examined, fAPAR anomalies were negative in 2001, 2002, 2003 and positive in other six years. The largest negative anomalies of $-15.2 \%$ and $-11.5 \%$ were obtained in 2002 and in 2001 , respectively. The maximum anomaly of $9.3 \%$ was obtained in 2005 . The existing variability due to climate impacts will be discussed in section 4.3.

The aerial average fAPAR for each eco-region (Figure 6) shows the differences in the inter-annual variation among these eco-regions. Cypress Upland and Mixed Grassland had experienced the largest inter-annual variation in fAPAR, followed by Moist Mixed Grassland, Fescue Grassland and Aspen Parkland. Lake Manitoba Plain had intermediate inter-annual variation, with an unusual low value in 2005. Boreal Transition had experienced the least variation between 0.73 and 0.81 . The variations in Aspen Parkland and Moist Mixed Grassland were observed to have a trend similar to the whole region variation, which was expected because these two eco-regions constituted $59.1 \%$ of the Prairie. Compared to the largest decrease of fAPAR in Aspen Parkland (-20.1\%) and in Moist Mixed Grassland (-20.6\%) in 2002, Cypress Upland and Mixed Grassland had the largest decrease in 2001(-38.5\% and $-30.7 \%$ respectively). The low fAPAR in these eco-regions resulted in low fAPAR in the whole Prairie from 2001 to 2003. The situation in Boreal Transition and Lake Manitoba Plain was much different. The lowest three years were 2005 to 2007 in Boreal Transition and 2004 to 2006 in Lake Manitoba Plain.

\subsection{Climate impacts}

Several climate factors could substantially influence plant growth and thereafter land surface fAPAR. The key factors can be different for different ecosystems, such as soil moisture in arid eco-regions and temperature in boreal eco-regions (Wang, et al. 2006, Wang and Davidson, 2007). In the semiarid Prairie, precipitation largely determines ecosystem water conditions which is the key factor in controlling vegetation growth and development, and hence land surface fAPAR. Our study showed that the Prairie was vulnerable to the high temporal and spatial variation of precipitation, which was also indicated in Bonsal and Wheaton (2005). Since our fAPAR values represented those in mid-July, annual precipitation in the discussion below referred to the accumulated amount of precipitation from $1^{\text {st }}$ September in the previous year to July $20^{\text {th }}$ of the year for fAPAR determination. During the study period, the dry years included 2001, 2002 and 2003 while the wettest year was 2005. In 2000, the southern Alberta region showed less than normal precipitation, resulting in poorer than normal vegetation growth. In 2001, the area with lower than normal precipitation spread eastward and covered most of the southern and central Alberta and Saskatchewan. In 2002 precipitation deficits moved northward where the percentage of average precipitation (based upon the 1961-1990 climate means) only had 40-60\%. In the vicinity of Edmonton, it was even lower than $40 \%$ (Drought Watch web site http://www.agr.gc.ca/pfra/drought/archives_e.htm). This led to the lowest fAPAR in Aspen Parkland and Moist Mixed Grassland eco-regions. In the southern Alberta and Saskatchewan region, the drought situation was improved due to two major large-scale weather systems associated with widespread rain and even heavy rain in some areas prior to mid July. The vegetation showed recovery in these areas after these two rain events. This can be seen from fAPAR in Mixed Grassland which increased to near normal and fAPAR in Cypress Upland which reached its highest value among the nine years. In 2003, much of Alberta and extreme south-western Saskatchewan was associated with near to greater than normal precipitation with the remainder of the region being below average. This resulted in low fAPAR in Aspen Parkland and Moist Mixed Grassland over the Saskatchewan region. In 2005, precipitation in most eastern regions of the Prairie was above average (115-150\%), with the remainder being around average. As a result, aerial average fAPAR for the entire Prairie reached highest in 2005. The results of this study indicated that high precipitation generally corresponded to high fAPAR in most cases over the region. This is not surprising because plant growth 
in the Prairie is generally constrained by water availability. Note that the fAPAR was unusually low near Winnipeg in 2005 while its precipitation was above average (115-150\%). This was caused by flooding from persistent heavy rains in June over the region.

Temperature is another climatic factor influencing plant growth and thereafter land surface fAPAR over the region. Its impact becomes more or less pronounced depending on different eco-regions and precipitation conditions. In 2002 , the north part of the region was very dry and the temperatures in June and July were $2^{\circ} \mathrm{C}$ higher than normal. Under the dry condition, higher temperature deteriorated the plant water condition as it increased the atmospheric demand for evapotranspiration. fAPAR showed the lowest in the nine years over the region. In 2006, temperature was $1-2^{\circ} \mathrm{C}$ higher than normal from April to July across the Prairie, but precipitation was around normal in most regions except Boreal Transition. fAPAR over those regions was around average. Higher temperature had more significant effect on fAPAR in more arid eco-region. For example, fAPAR in Mixed Grassland was found to have more significant reduction than that in Fescue Grassland in warmer years.

\section{Conclusion}

The fAPAR in the Canadian Prairie for the period of 2000 to 2008 were estimated in this study using the MODIS data and the land surface model EALCO produced and developed in Canada Centre for Remote Sensing. The CCRS MODIS 10-day composites of surface reflectance and the EALCO model include a number of advancements previously made. These advancements include: (1) the reduction of MODIS image distortion in Canada inherent to the sinusoidal (SIN) projection utilized in the standard MODIS data products, (2) the downscaling of MODIS 500m land bands of B3 to B7 to $250 \mathrm{~m}$ for compatibility with $250 \mathrm{~m}$ bands B1 and B2, (3) the separation of satellite forward scattering and backward scattering (relative the sun) in producing the clear sky composites to account for surface bi-directional properties, (4) the capability in simulating narrowband and broadband spectral reflectance and vegetation index (e.g., NDVI) in the EALCO model, and (5) its algorithms developed for simulating land surface radiation processes to include the heterogeneities of stands and the multi-scattering processes within canopy and between canopy and the background, etc.. The estimated fAPAR were compared with field measurements. Results showed that the average absolute error between observed and modeled fAPAR was 0.035 .

The Prairie was divided into seven eco-regions of Aspen Parkland, Moist Mixed Grassland, Fescue Grassland, Mixed Grassland, Cypress Upland, Lake Manitoba Plain and Boreal Transition, mainly according to their vegetation types, soil types, and precipitation. In the peak growing season (July $11^{\text {th }}$ to $20^{\text {th }}$ ), the areal average fAPAR during 2000-2008 was 0.56. The spatial patterns of fAPAR were predominately determined by the land cover types over each eco-region. Aspen Parkland had the highest fAPAR associated with trembling aspen and mixed tall shrubs under the favorable conditions of precipitation and black soil. Mixed Grassland had the lowest fAPAR associated with pasture and rangeland under the conditions of limited precipitation and infertile brown soil.

The inter-annual variation of fAPAR was significant over the region. The consecutive droughts from 2001 to 2003 in Prairie resulted in substantial reduction in fAPAR. Among the nine study years of 2000-2008, the areal average varied from its lowest value of 0.48 in 2002 to its highest value of 0.62 in 2005. The Mixed Grassland eco-region had the largest inter-annual variation (from 0.28 in 2001 to 0.48 in 2005) and the Boreal Transition eco-region had the smallest inter-annual variation (from 0.73 in 2006 to 0.81 in 2001). The spatial patterns of the fAPAR inter-annual variation were found to be highly consistent with the spatial patterns of the precipitation inter-annual variation, indicating that precipitation was the key factor in controlling the fAPAR dynamics over the region. Indeed, in semiarid grasslands like the Prairie, the amount and time of precipitation play an essential role in affecting the ecosystem water condition and hence the vegetation growth. The variation of temperature had the secondary role to precipitation in affecting fAPAR over the region. Under low precipitation conditions, high temperature could increase the plant water stress and decrease fAPAR, as in the case in 2002 in the northern part of the Prairie.

Atmospheric conditions which determine the direct vs. diffuse radiation components in the total radiation (e.g., clear vs. overcast sky) and the solar zenith angle also affects the magnitudes of fAPAR. In this paper, we did not include these analyses due to the fact that the MODIS data used were the 10-day clear-sky composites and normalized to the solar noon angle. The variation of solar zenith angle at noon over the region was small during the study period. It is worth noting that fAPAR at noon when the solar zenith angle was smallest tends to be smaller than that in the morning and late afternoon, as found from both modeling (e.g., Wang et al., 2007) and in situ observation (e.g., Fensholt et al., 2004). This study is an initial step toward generating fAPAR products over large regions through assimilating satellite data in the EALCO model and improving our understanding of fAPAR variation with climate factors for the Canadian ecosystems. 


\section{References}

Akinremi, O. O., \& McGinn, S.M. (2001). Seasonal and spatial patterns of rainfall trends on the Canadian Prairies. J. Climate, 2177 - 2182. http://dx.doi.org/10.1175/1520-0442(2001)014<2177:SASPOR >2.0.CO;2

Begué, A. (1993). Leaf area index, intercepted photosynthetically active radiation, and spectral vegetation indices: A sensitivity analysis for regular-clumped canopies. Remote Sens. Environ., 46, 45-59. http://dx.doi.org/10.1016/0034-4257(93)90031-R

Bonsal, B., \& Wheaton, E. (2005). Atmospheric circulation comparison between the 2001 and 2002 and the 1961 and 1988 Canadian prairie droughts. Atmosphere-Ocean, 43(2), 163-172. http://dx.doi.org/10.3137/ao.430204

Fensholt, R. et al. (2004). Evaluation of MODIS LAI, fAPAR and relation between fAPAR and NDVI in a semi-arid environment using in situ measurements. Remote Sens. Environ., 91, 490-507. http://dx.doi.org/10.1016/j.rse.2004.04.009

Global Climate Observing System (GCOS). (2003), Summary report of the eleventh session of the WMO-IOC-UNEP-ICSU, Rep. WMO/TD 1189 GCOS-87, World Meteorol. Organ., Geneva, Switzerland.

GCOS. (2006). Systematic observation requirements for satellite-based products for climate: Supplemental details to the satellite-based component of the "Implementation plan for the Global Observing System for Climate in support of the UNFCC (GCOS-92)", GCOS-107, September 2006, WMO/TD-1338. 103 pp.

Global Terrestrial Observing System. (2008). Terrestrial essential climate variables for assessment, mitigation and adaptation. Terrestrial essential climate variables for assessment, mitigation and adaptation, Rep. GTOS-52, edited by R. Sessa and H. Dolman, Food and Agric. Organ. of the U. N., Rome.

Gobron, N. et al. (1997). A semi-discrete model for the scattering of light by vegetation. J. Geophys. Res., 102, 9431-9446. http://dx.doi.org/10.1029/96JD04013

Gobron, N. et al. (2006). Moderate Resolution Imaging Spectroradiometer, JRC-FAPAR algorithm theoretical basis document. EUR Report No. 22164 EN, Institute for Environment and Sustainability.

Gobron, N. et al. (2010). Monitoring Biosphere Vegetation 1998-2009. Geophys. Res. Lett., VOL. 37, L15402, http://dx.doi.org/10.1029/2010GL043870

Hanesiak J.M. et al. (2011). Characterization and summary of the 1999-2005 canadian prairie drought. Atmosphere-Ocean. http://dx.doi.org/10.1080/07055900.2011.626757

Hatfield, J. L. et al. (1984). Intercepted photosynthetically active radiation estimated by spectral reflectance. Remote Sens. Environ, 14, 65-75. http://dx.doi.org/10.1016/0034-4257(84)90008-7

Knorr W., \& Kattge, J. (2005). Inversion of terrestrial biosphere model parameter values against eddy covariance measurements using Monte Carlo sampling. Global Change Biology, 11, 1333-1351. http://dx.doi.org/10.1111/j.1365-2486.2005.00977.x

Knyazikhin, Y. et al. (1998). Synergistic algorithm for estimating vegetation canopy leaf area index and fraction of absorbed photosynthetically active radiation from MODIS and MISR data. J. Geophys. Res., 103(D24), 322257-32275._http://dx.doi.org/10.1029/98JD02462

Latifovic, R., \& Pouliot, D. (2005). Multitemporal land cover mapping for Canada: Methodology and products. Can. J. Remote Sens., 31, 347-363. http://dx.doi.org/10.5589/m05-019

Leblanc, S. G. (2002). Correction to the plant canopy gap size analysis theory used by the Trancing Radiation and Architecture of Canopies instrument. Applied Optics, 31, 7667-7670.

Le Roux X. et al. (1997). Radiation absorption and use by humid savanna grassland: assessment using remote sensing and modelling. Agric. For. Meteorol., 85, 117-132. http://dx.doi.org/10.1016/S0168-1923(97)00002-6

Luo, Y. et al. (2008). Developing clear-sky, cloud and cloud shadow mask for producing clear-sky composites at 250-meter spatial resolution for the seven MODIS land bands over Canada and North America. Remote Sens. Environ., 112, 4167-4185.http://dx.doi.org/10.1016/j.rse.2008.06.010

Nilson, T. (1999). Inversion of gap frequency data in forest stands. Agric For Meteorol, 98-99, 437-448. http://dx.doi.org/10.1016/S0168-1923(99)00114-8

Pinty, B. et al. (2007). Retrieving surface parameters for climate models from MODIS-MISR albedo products. $J$. Geophys. Res., 112. http://dx.doi.org/10.1029/2006JD008105

Plummer, S. et al. (2006). Establishing an Earth observation product service for the terrestrial carbon community: the GLOBCARBON initiative Mitigation and Adaptation Strategies for Global Change, 11, 97-111. $\mathrm{http}: / / \mathrm{dx}$. doi.org/10.1007/s11027-006-1012-8 
Prince, S. D. (1991). Lite remote sensing of primary production: Comparison of results for Sahelian grasslands 1981-1988. Int. J. Remote Sensing, 12, 1301-1311. http://dx.doi.org/10.1080/01431169108929727

Prince, S. D., \& Goward, S. N. (1995). Global primary production: A remote sensing approach. Journal of Biogeography, 22, 815-835. http://dx.doi.org/10.2307/2845983

Running, S.W. et al. (1999). MODIS daily photosynthesis (PSN) and annual net primary production (NPP) product (MOD17). Algorithm Theoretical Basis Document Version 3.0.

Sellers, P. J. et al. (1996). A revised land surface parameterization SiB2 for atmospheric GCMs: II. The generation of global field fields of terrestrial biophysical parameters from satellite data. Journal of Climate, 94(4), 706 - 737. http://dx.doi.org/10.1175/1520-0442(1996)009<0706:ARLSPF>2.0.CO;2

Wang, S. (2005). Dynamics of land surface albedo for a boreal forest and its simulation. Ecol Model. 183:477-494. http://dx.doi.org/10.1016/j.ecolmodel.2004.10.001.

Wang, S. et al. (2006). Comparison of International Panel on Climate Change Fourth Assessment Report climate model simulations of surface albedo with satellite products over northern latitudes. J. Geophys. Res., 111, D21108. http://dx.doi.org/10.1029/2005JD006728.

Wang, S., \& Davidson, A. (2007). Impact of climate variations on surface albedo of a temperate grassland. Agric. For. Meteorol., 142, 133-142. http://dx.doi.org/10.1016/j.agrformet.2006.03.027

Wang, S. et al. (2007). Simulation of canopy radiation transfer and surface albedo in the EALCO model. Climate Dynamics, 29:615-632. http://dx.doi.org/10.1007/s00382-007-0252-y.

Wang, S. (2008). Simulation of evapotranspiration and its response to plant water and CO2 transfer dynamics. Journal of Hydrometeorology, 9: 426-443. http://dx.doi.org/10.1175/2007JHM918.1

Wheaton, E. et al. (2008). Dry Times: Lessons from the Canadian Drought of 2001 and 2002. The Canadian Geographer, 52(2): 241- 262. Saskatchewan Research Council (SRC) Publication No. 11927-6A06.

Widlowski, J-L. et al. (2011). RAMI4PILPS: An Intercomparison of Formulations for the Partitioning of Solar Radiation in Land Surface Models. J. Geophys. Res., 116, G02019. http://dx.doi.org/10.1029/2010JG001511

Table 1. The Prairie eco-region classes and their description

(http://www.ec.gc.ca/soer-ree/English/Framework/NarDesc/praire_e.cfm)

\begin{tabular}{|c|c|c|c|c|c|}
\hline $\begin{array}{l}\text { Eco-region } \\
\text { type }\end{array}$ & Vegetation type & $\begin{array}{c}\text { Dominant soil } \\
\text { type }\end{array}$ & $\begin{array}{l}\text { Mean } \\
\text { annual/summer } \\
\text { temperature }\left({ }^{\circ} \mathrm{C}\right)\end{array}$ & $\begin{array}{l}\text { Mean annual } \\
\text { precipitation } \\
\quad(\mathrm{mm})\end{array}$ & $\begin{array}{l}\text { Area } \\
(\%)\end{array}$ \\
\hline $\begin{array}{l}\text { Aspen } \\
\text { Parkland }\end{array}$ & $\begin{array}{l}\text { Most is now farmland. It produces a } \\
\text { wide diversity of crops, including } \\
\text { spring wheat, other cereals, oilseeds, } \\
\text { and forages. The landscape was } \\
\text { characterized by trembling aspen, oak } \\
\text { groves, mixed tall shrubs, and } \\
\text { intermittent fescue grasslands. }\end{array}$ & $\begin{array}{c}\text { Black } \\
\text { Chernozemic } \\
\text { soils }\end{array}$ & $1.5 / 15$ & $400-500$ & 37.6 \\
\hline $\begin{array}{l}\text { Moist } \\
\text { Mixed } \\
\text { Grassland }\end{array}$ & $\begin{array}{l}\text { Spring wheat and other cereals are } \\
\text { produced. Oilseed crops are } \\
\text { becoming increasingly important. } \\
\text { Pasturelands are dominated by spear } \\
\text { grass and wheat grass, and deciduous } \\
\text { shrubs. }\end{array}$ & $\begin{array}{l}\text { Dark Brown } \\
\text { Chernozemic } \\
\quad \text { soils }\end{array}$ & $2.5 / 15.5$ & $350-400$ & 21.5 \\
\hline $\begin{array}{l}\text { Fescue } \\
\text { Grassland }\end{array}$ & $\begin{array}{l}\text { The northern section is almost } \\
\text { completely cultivated. The southern } \\
\text { section has a mixture of cultivation } \\
\text { on the flatter portions and ranching } \\
\text { on the rougher, ridged components of } \\
\text { the uplands and foothills. }\end{array}$ & $\begin{array}{l}\text { Black } \\
\text { Chernozemic } \\
\text { soils }\end{array}$ & $3.5 / 14$ & $400-450$ & 3.2 \\
\hline $\begin{array}{l}\text { Mixed } \\
\text { Grassland }\end{array}$ & $\begin{array}{l}\text { About half region is cultivated with } \\
\text { the remainder being used for pasture } \\
\text { or rangeland. It produces spring }\end{array}$ & $\begin{array}{c}\text { Brown } \\
\text { Chernozemic } \\
\text { soils }\end{array}$ & $3.5 / 16$ & $250-350$ & 28.9 \\
\hline
\end{tabular}




\begin{tabular}{|c|c|c|c|c|c|}
\hline & $\begin{array}{l}\text { wheat, other cereals and flaxseed. The } \\
\text { natural vegetative cover is dominated } \\
\text { by spear grass, blue grama grass, and } \\
\text { wheat grass. }\end{array}$ & & & & \\
\hline $\begin{array}{l}\text { Cypress } \\
\text { Upland }\end{array}$ & $\begin{array}{l}\text { Vegetation ranges from fescue, } \\
\text { wheatgrass grasslands below } 1000 \mathrm{~m} \\
\text { to a mixed montane-type open forest } \\
\text { of pine, deciduous trees, and shrubs at } \\
\text { upper elevations. It allows livestock } \\
\text { grazing and limited production of } \\
\text { cereals on smoother lower slopes. }\end{array}$ & $\begin{array}{l}\text { Black and Dark } \\
\text { Brown } \\
\text { Chernozemic } \\
\text { soils }\end{array}$ & $3 / 15.1$ & $400-500$ & 1.9 \\
\hline $\begin{array}{l}\text { Lake } \\
\text { Manitoba } \\
\text { Plain }\end{array}$ & $\begin{array}{l}\text { It is a mosaic of trembling aspen/oak } \\
\text { groves and rough fescue grasslands. } \\
\text { Its growing season length, available } \\
\text { heat, and precipitation permit the } \\
\text { production of corn, spring wheat, and } \\
\text { other cereal grains. }\end{array}$ & $\begin{array}{c}\text { Black } \\
\text { Chernozemic } \\
\text { soils }\end{array}$ & $3.1 / 16$ & $450-700$ & 6.4 \\
\hline $\begin{array}{l}\text { Boreal } \\
\text { Transition }\end{array}$ & $\begin{array}{l}\text { Upper elevations have a closed cover } \\
\text { of tall trembling aspen with } \\
\text { secondary quantities of balsam } \\
\text { poplar, an understory of tall shrubs, } \\
\text { and a ground cover of mixed herbs. } \\
\text { Lower elevations have the production } \\
\text { of spring wheat, other cereals, } \\
\text { oilseeds, and hay crops. }\end{array}$ & $\begin{array}{c}\text { Dark Gray } \\
\text { Chernozemic } \\
\text { soils }\end{array}$ & $2.5 / 16$ & $450-700$ & 0.5 \\
\hline
\end{tabular}

Table 2. Parameters used in the model

\begin{tabular}{|c|c|c|}
\hline \multicolumn{1}{|c|}{ Parameter } & cropland & grassland \\
\hline Stand density $\left(\mathrm{m}^{-2}\right)$ & 12 & 100 \\
\hline Height (m) & $0.3-1.9$ & $0.1-0.7$ \\
\hline Crown radius (m) & $0.2-0.6$ & $0.08-0.6$ \\
\hline Clumping index & 0.8 & 0.8 \\
\hline VIS reflectance & & \\
\hline Leaf adaxial/abaxial & 0.06 & 0.06 \\
\hline Saturated soil & 0.20 & 0.20 \\
\hline RED reflectance & & 0.06 \\
\hline Leaf adaxial/abaxial & 0.06 & 0.26 \\
\hline Saturated soil & 0.26 & \\
\hline NIR reflectance & & 0.30 \\
\hline Leaf adaxial/abaxial & 0.31 & 0.40 \\
\hline Saturated soil & 0.40 & \\
\hline VIS transmittance & & 0.05 \\
\hline Leaf adaxial/abaxial & 0.05 & \\
\hline RED transmittance & & \\
\hline Leaf adaxial/abaxial & 0.06 & \\
\hline NIR transmittance & & \\
\hline Leaf adaxial/abaxial & 0.31 & \\
\hline
\end{tabular}


Table 3. Site descriptions including name, latitude, longitude, vegetation type and growth stage

\begin{tabular}{|c|c|c|c|c|}
\hline Site & Lat & Lon & Vegetation type & growth stage \\
\hline Canola1 & 50.43 & -105.74 & canola & Rosette stage \\
\hline Canola2 & 52.13 & -106.82 & canola & Bolting stage \\
\hline Canola3 & 49.83 & -111.72 & canola & Full flowering stage \\
\hline Wheat1 & 52.13 & -106.81 & wheat & Head emergence stage \\
\hline Wheat2 & 52.06 & -108.24 & wheat & Flowing stage \\
\hline Wheat3 & 50.40 & -107.27 & wheat & Grain filling stage \\
\hline Wheat4 & 50.40 & -104.57 & wheat & Grain filling stage \\
\hline Wheat5 & 49.94 & -110.83 & wheat & Grain filling stage \\
\hline Corn1 & 49.81 & -112.03 & corn & V6 \\
\hline Grass1 & 52.13 & -107.08 & grass & \\
\hline Grass2 & 52.06 & -108.34 & grass & \\
\hline Grass3 & 50.65 & -113.06 & grass & \\
\hline
\end{tabular}

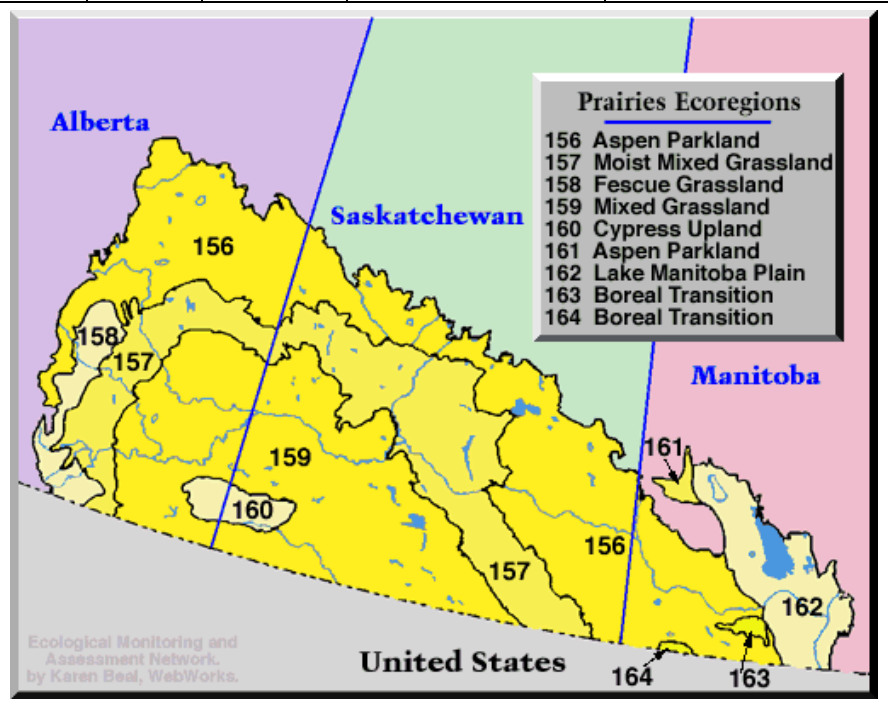

Figure 1. The Canadian Prairie eco-zone and eco-regions (from http://www.ec.gc.ca/soer-ree/English/Framework/NarDesc/praire_e.cfm)



Figure 2. Comparison of modeled vs. observed fAPAR 



Figure 3. The 9-year average fAPAR over the Prairies during July $11^{\text {th }}-20^{\text {th }}$


Figure 4. Spatial distributions of fAPAR in $2000-2008$ over the prairies during July $11^{\text {th }}-20^{\text {th }}$ 




Figure 5. fAPAR anomaly for the Prairie in 2000-2008 during July $11^{\text {th }}-20^{\text {th }}$



Figure 6. Average fAPAR for each eco-region in 2000-2008 during July $11^{\text {th }}-20^{\text {th }}$ 